e-ISSN : 2621-4105

\title{
KEDUDUKAN KOMISI PEMBERANTASAN KORUPSI DALAM SISTEM KETATANEGARAAN DI INDONESIA
}

\author{
Bambang Sadono, Ali Lubab, Zaenal Arifin, Kadi Sukarna \\ Magister Hukum Universitas Semarang, Semarang \\ bambangsadono@usm.ac.id
}

\begin{abstract}
ABSTRAK
Penelitian ini bertujuan untuk mengkaji bagaimana kedudukan Komisi Pemberantasan Korupsi dalam sistem ketatatnegaraan di Indonesia. Salah satu hasil dari Perubahan Undang-undang Dasar Negara Republik Indonesia Tahun 1945 UUD Negara RI Tahun 1945 adalah beralihnya supremasi Majelis Permusyawaratan Rakyat (MPR) menjadi supremasi konstitusi. Sementara itu, konstitusi diposisikan sebagai hukum tertinggi yang mengatur dan membatasi kekuasaan lembaga-lembaga negara. Penelitian ini menggunakan menggunakan metode penelitian yuridis normatif. Perkembangan konsep trias politica juga turut memengaruhi perubahan struktur kelembagaan di Indonesia. Untuk menjawab tuntutan tersebut, negara membentuk jenis lembaga negara baru yang diharapkan dapat lebih responsif dalam mengatasi persoalan aktual negara. Maka, berdirilah berbagai lembaga negara salah satunya adalah Komisi Pemberantasan Korupsi (KPK) keberadaan yang keberadaannya dalam struktur ketatanegaraaan di negeri ini sering menjadi perdebatkan oleh berbagai pihak karena Komisi Pemberantasan Korupsi Sifat yang independen dan bebas dari pengaruh kekuasaan. Permasalahan yang ingin dijawab dalam penelitian ini adalah Kedudukan Komisi Pemberantasan Korupsi dalam Sistem Ketatanegaraan di Indonesia saat ini dan Kedudukan Komisi Pemberantasan Korupsi yang seharusnya dalam Sistem Ketatanegaraan di Indonesia,teori yang di gunakan dalam penelitian ini adalah trias politica dan kepastian hukum, penelitian ini adalah penelitian hukum normatif. Kesimpulan penelitian ini adalah keberadaan lembaga Komisi Pemberantasan Korupsi secara yuridis adalah sah berdasarkan konstitusi dan secara sosiologis telah menjadi kebutuhan bangsa dan Negara Republik Indonesia. Untuk mewujudkan Komisi Pemberantasan Kosupsi bebas dari pengaruh kekuasaan manapun dan Kedududukan Komisi Pemberantasan Korupsi dalam sistem ketatanegaran di Indonesia akan menjadi lebih kuat maka kedudukannya menjadi organ konstitusi (constitusional organs) atau masuk kedalam konstitusi maka di perlukan Amandemen Undang-undang Dasar Negara Republik Indonesia Tahun 1945.
\end{abstract}

Kata Kunci : Sistem Ketatanegaraan; Kedudukan; Pemberantasan Korupsi 
e-ISSN : 2621-4105

\title{
POSITION OF THE CORRUPTION ERADICATION COMMISSION IN THE STATE SYSTEM IN INDONESIA
}

\begin{abstract}
This study aims to examine how the position of the Corruption Eradication Commission in the state administrative system in Indonesia. One of the results from the 1945 Constitution of the Republic of Indonesia amendment is the changes supremacy from the People's Consultative Assembly to constitutional supremacy. while the constitution is positioned as the highest rule for regulate and limit the power of state institution. trias politica consept development also affecting the shifts on institutional structure in Indonesia. as answers for all demand, state establish a new institution which expected can be more responsive to addressing occurred state problems. therefore various institution is established, one of them is Komisi Pemberantasan Korupsi (KPK) which the existence in constitutional structure is often become debating by various party because it's have an independent nature and free from influence any kind of power. this thesis addressing problem about position of Komisi Pemberantasan Korupsi at current condition and how should it be on constitutional law system in Indonesia, this is a normative legal research. Based on the research, the existence of Komisi Pemberantasan Korupsi, juridically legitimate according on constitution and sociologically become a necessity for the nation of Indonesia. UUD 1945 amendment is needed for the Komisi Pemberantasan Korupsi to growth become constitutional organ or include into the constitution in order to creating an Komisi Pemberantasan Korupsi which free from any kind of power influences and stronger position on constitutional law system.
\end{abstract}

Keywords: Constitutional Law System; Position; Corruption Eradication 
e-ISSN : 2621-4105

\section{A. PENDAHULUAN}

Perubahan pemikiran masyarakat berakibat terhadap struktur lembaga negara, termasuk bentuk dan fungsi organisasi-organisasi negara di Indonesia. Sebagai konsekuesi dari perkembangan zaman, munculah organisasi-organisasi negara baru yang berupa dewan (council), komisi (commission), komite (committee), badan (board), atau otorita (authority). ${ }^{1}$

Pada kondisi di Indonesia, cenderung berdiri organisasi-organisasi negara baru terjadi sebagai akibat dari amandemen Undang-undang Dasar Negara Republik Indonesia Tahun 1945. Organisasi-organisasi negara baru tersebut biasa dikenal dengan sebutan state auxiliary organs atau state auxiliary institutions yang di terjemahkan dalam bahasa Indonesia adalah sebagai organisasi negara bantu dan merupakan organisasi negara yang berfungsi sebagai penunjang organisasi lain. Sebagian organisasi-organisasi tersebut di kenal juga sebagai self regulatory agencies, independent supervisory bodies, atau organisasi-organisasi yang menjalankan fungsi campuran (mix-function) antara fungsifungsi regulasi, administatif, dan fungsi pengadilan yang biasanya dipisah-pisahkan akan tetapi malah dijalankan secara bersama oleh organisasi-organisasi baru tersebut. ${ }^{2}$

Sejak pendiriannya sampai dengan sekarang yang kurang lebih tujuh belas tahun, keberadaan dan kedudukan Komisi Pemberantasan Korupsi dalam struktur ketatanegaraaan di negeri ini sering menjadi perdebatkan oleh berbagai pihak, Komisi Pemberantasan Korupsi (KPK) dianggap oleh sebagian ahli sebagai organisasi ekstrakonstitusional. ${ }^{3}$

Penelitian ini terkait deenga penelitian Ismail Aris (2018) yang mengkaji tentang Kedudukan KPK Dalam Sistem Ketatanegaraan Dalam Perspektif Teori The New Separation Of Power, dalam peneltiannya tersebut menjelaskn bahwa pada faktanya dalam

\footnotetext{
${ }^{1}$ Jimly Asshiddiqie (b), Perkembangan dan Konsolidasi Organisasi Negara Pasca Reformasi, Sekretaris Jenderal dan Kepaniteraan Mahkamah Konstitusi RI, Jakarta, 2006, hlm. V.

${ }^{2}$ Ibid.

${ }^{3}$ Para pemohon pengujian Undang-undang Nomor 30 Tahun 2002 tentang Komisi Pemberantasan Tindak Pidana Korupsi terhadap Undang-undang Dasar Negara Republik Indonesia Tahun 1945, yang terdiri dari Mulyana Wirakusumah, Nazaruddin Sjamsuddin, dkk., dan Capt. Tarcisius Walla, menilai KPK sebagai organisasi ekstrakonstitusional karena telah mengambil alih kewenangan organisasi lain yang diperoleh dari Undang-undang Dasar Negara Republik Indonesia Tahun 1945yang sebetulnya telah terbagi habis dalam kekuasaan eksekutif, legislatif, dan yudikatif. Lihat Putusan MK RI Nomor 012-016-019/PUUIV/2006, hlm. 33.
} 
e-ISSN : 2621-4105

sistem ketatanegaraan, menunjukkan bahwa Komisi Pemberantasan Korupsi sebagai independen organ dan tidak lagi dapat didudukkan sebagai lembaga eksekutif, serta tidak relevan lagi menggolongkan suatu lembaga negara pada 3 (tiga) cabang kekuasaan an sich, sebagaimana teori trias politica. Pada fakatnya diatas bahwa kelahiran komisi independen dapat menjalankan kekuasaan dan kewenangan lembaga sebelumnya pada rumpun eksekutif dan dialihkan menjadi lembaga independen. Bahkan tugas dan kewenangan komisi independen dapat saja bersifat quasi yudikatif dan quasi legislative. ${ }^{4}$

Penelitian dari Yopa Puspitasari (2019) lebih mengkaji mengenai kedudukan Komisi Pemberantasan Korupsi dalam struktur ketatanegaraan indonesia ditinjau dari hukum Islam. Hasil dari penelitian tersebut menjelaskan bahwa masalah kedudukan Komisi Pemberantas Korupsi tersebut diatur dalam UU Nomor 30 Tahun 2002, dimana lembaga Komisi Pemberantas Korupsi menurut UU tersebut, merupakan lembaga yang independen yang bebas dari pengaruh kekuasaan manapun. Walaupun lembaga Komisi Pemberantas Korupsi bukan termasuk lembaga utama yang diatur UUD 1945 melainkan Komisi yang diatur UU, namun secara kedudukannya sama dengan lembaga-lembaga yang diatur dalam UUD 1945. Sedangakan Wilayah Al-Mazalim adalah suatu kekuasaan peradilan yang lebih tinggi dari Wilayah Al-Qadha', dan Wilayah al-Hisbah, yakni menyelesaikan perkara yang tidak dapat diselesaikan oleh kedua lembaga peradilan tersebut, yaitu masalah penganiayaan yang dilakukan oleh para penguasa, hakim-hakim, atau keluarganya. Selain itu Wilayah Al-Mazhalim bersifat independen yang tidak ada intervensi oleh Kepala Negara atau Pejabat Negara. ${ }^{5}$

Sedangkan penelitian oleh Mellysa Febriani Wardojo dan Didik Endro Purwoleksono (2018) mengkaji tentang kedudukan Komisi Pemberantasan Korupsi sebagai lembaga negara, hasil penelitian tersebut menjelaskan KPK merupakan independent agency,disamping itu KPK merupakan lembaga negara yang dibentuk berdasarkan perintah undang-undang (legislatively entrusted power). KPK merupakan lembaga yang bersifat Ad Hoc yang berarti memiliki tugas khusus dalam menjalankan wewenangnya

\footnotetext{
${ }^{4}$ Ismail Aris, Kedudukan KPK Dalam Sistem Ketatanegaraan Dalam Perspektif Teori The New Separation Of Power, Jurnal Jurisprudentie 5(1), 2018, hlm 98-114.

https://doi.org/10.24252/jurisprudentie.v5i2.5433

${ }^{5}$ Yopa Puspitasari, Kedudukan Komisi Pemberantasan Korupsi Dalam Struktur Ketatanegaraan Indonesia Ditinjau Dari Hukum Islam, Jurnal Al-Imarah: Jurnal Pemerintahan dan Politik Islam 4 (2), 2019, hlm 163-176. http://dx.doi.org/10.29300/imr.v4i2.2830
} 
e-ISSN : 2621-4105

untuk memberantas tindak pidana korupsi di indonesia dengan jangka waktu yang tidak ditentukan. ${ }^{6}$

Penelitian ini lebih fokus mengkaji bagaimana kedudukan Komisi Pemberantasan Korupsi dalam sistem ketatanegaraan di Indonesia serta bagaimana kedudukan yang ideal bagi Komisi Pemberantasan Korupsi dalam sistem ketatanegaraan Indonesia. Permasalahan yang diangkat dalam penelitian ini berbeda dengan penelitian sebelumnya. Penelitian ini melengkapi dari permasalahan yang belum diangkat pada penelitian sebelumnya. Penelitian dari dari Ismail Aris mengkaji kedudukan KPK dalam perspektif teori pembagian kekuasaan, sedangkan penelitian dari Yopa Puspitasari mengangkat permasalahan kedudukan KPK dalam perspektif Hukum Islam. Penelitian dari Mellysa Febriani Wardojo dan Didik Endro Purwoleksono memberikan kesimpulan bahwa KPK merupakan lembaga yang bersifat Ad Hoc yang dibentuk berdasarkan undang-undang. Penelitian ini bertujuan untuk mengkaji bagaimana kedudukan Komisi Pemberantasan Korupsi dalam sistem ketatatnegaraan di Indonesia.

\section{B. PERMASALAHAN}

Berdasarkan latar belakang diatas, maka penulis dapat merumuskan masalah yang akan menjadi acuan dalam penelitian ini yaitu :

1. Bagaimana Kedudukan Komisi Pemberantasan Korupsi dalam Sistem Ketatanegaraan di Indonesia?

2. Bagaimana Kedudukan Komisi Pemberantasan Korupsi yang seharusnya dalam Sistem Ketatanegaraan di Indonesia?

\section{METODE PENELITIAN}

Memperhatikan apa yang menjadi permasalahan dari penelitian ini, maka metode pendekatan yang dipilih untuk diterapkan dalam penelitian ini adalah penelitian hukum yuridis normatif dimana penelitian yang dilakukan dengan cara meneliti bahan hukum pustaka atau data sekunder. $^{7}$

Penelitian hukum normatif tentang "kedudukan komisi pemberantasan korupsi dalam sistem ketatanegaraan di indonesia" ini dimulai dengan melakukan inventarisasi hukum

\footnotetext{
${ }^{6}$ Mellysa Febriani Wardojo,Didik Endro Purwoleksono, Kedudukan Komisi Pemberantasan Korupsi Sebagai Lembaga Negara, Jurnal Legal Standing 2(1), 2018, hlm 73-83.

https://doi.org/10.24252/jurisprudentie.v5i2.5433

${ }^{7}$ Soerjono Soekanto dan Sri Mamudji, Penelitian Hukum Normatif Suatu Tinjauan Singkat, PT. Raja Grafindo Persada, Jakarta 2007, hal. 13-14.
} 
e-ISSN : 2621-4105

positif, dalam hal ini yang Penulis kumpulkan adalah peraturan perundang-undangan yang berkaitan dengan kekuasaan Kehakiman dan Kejaksaan. Jika mengacu pada buku karangan Soerjono Soekanto yang berjudul "Penelitian Hukum Normatif Suatu Tinjauan Singkat", Penulis melakukan penelitian ini dengan metode pendekatan perundang-undangan (statute approach)

\section{PEMBAHASAN}

\section{Kedudukan Komisi Pemberantasan Korupsi Dalam Sistem Ketatanegaraan Di Indonesia}

Pesatnya pembentukan lembaga-lembaga baru, yang sebagian besar merupakan komisi negara independen merupakan gejala yang mendunia, dan disebabkan karena terjadi berbagai perubahan sosial dan ekonomi. Hal ini memaksa banyak negara melakukan eksperimentasi kelembagaan melalui pembentukan berbagai organ negara yang dinilai lebih efektif, powerful ${ }^{8}$, dan tentu saja akomodatif terhadap tuntutan rakyat. Di Indonesia, gerakan reformasi merupakan kesepakatan luhur bangsa, yang menjadi pijakan amandemen UUD Negara Republik Indonesia Tahun 1945, dan rahim bagi pembentukan komisi negara independen ${ }^{9}$ salah satunya adalah komisi Pemberatasan Korupsi.

Terkait tentang luasnya kewenangan yang dimiliki KPK ada potensi kekaburan norma dalam pemberian wewenang Lembaga tersebut. Penyebab utama adanya kekaburan norma dalam kewenangan lembaga negara tersebut adalah Undang-Undang KPK, termasuk Undang-Undang Tipikor itu sendiri. Karena Undang-Undanglah yang masih belum bisa memberikan penjelasan terkaitmengenai unsur-unsur yang telah dimuat dalam UndangUndang sebagai kewenangan lembaga Negara itu sendiri. ${ }^{10}$

Komisi Pemberantasan Korupsi adalah lembaga negara dalam rumpun kekuasaan eksekutif yang dalam melaksanakan tugas dan wewenangnya bersifat independen dan bebas dari pengaruh kekuasaan manapun. ${ }^{11}$ Selanjutnya, penjelasan pasal tersebut menguraikan sebagai berikut :

${ }^{8}$ Adri Fernando Roleh, Kedudukan Komisi Pemberantasan Korupsi Dalam Sistem Ketatanegaraan Indonesia, Lex Privatum 5 (10), 2017.

${ }^{9}$ Gunawan A. Tauda, Komisi Negara Independen (Eksistensi Independent Agencies sebagai Cabang Kekuasaan baru dalam Sistem Ketatanegaraan), Genta Press, Yogyakarta, 2012, hal. 88-89

${ }^{10}$ Aryas Adi Suyanto, "Komisi Pemberantasan Korupsi Sebagai Lembaga Rasuah dalam Pemberantasan Tindak Pidana Korupsi di Indonesia”, Jurnal USM Law Review 1(1), 2018, hal 42. DOI: 10.26623/julr.v1i1.2231.

${ }^{11}$ Undang-undang No 19 Tahun 2019 Op.Cit. Pasal 3 
e-ISSN : 2621-4105

"Yang dimaksud dengan "Lembaga Negara" adalah lembaga Negara yang bersifat sebagai State auxiliary agency yang masuk dalam rumpun eksekutif. Dalam ketentuan ini yang dimaksud dengan "kekuasaan manapun" adalah kekuasaan yang dapat mempengaruhi tugas dan wewenang komisi pemberantasan korupsi atau anggota komisi secara individu dari pihak eksekutif, yudikatif, legislatif, pihak-pihak lain yang terkait denga perkara tindak pidana korupsi, atau keadaan dan situasi ataupun dengan alasan apapun." 12

Satu hal yang perlu ditegaskan terkait dengan kedudukan Komisi Pemberantasan Korupsi adalah bahwa rumusan dalam Pasal 3 Undang-undang No 19 Tahun 2019 Tentang Perubahan Kedua Atas Undang-Undang Nomor 30 Tahun 2002 Tentang Komisi Pemberantasan Tindak Pidana Korupsi tidak memberikan kemungkinan adanya penafsiran lain selain yang terumuskan dalam ketentuan pasal tersebut, yaitu independensi dan kebebasan Komisi Pemberantasan Korupsi dari pengaruh kekuasaan manapun dalam melaksanakan tugas dan wewenangnya. ${ }^{13}$ Independensi dan kebebasan dari pengaruh kekuasaan manapun dalam pelaksanaan tugas dan wewenang Komisi Pemberantasan Korupsi juga perlu ditegaskan agar tidak terdapat keragu- raguan dalam diri anggota Komisi Pemberantasan Korupsi, sebagaimana telah diuraikan sebelumnya, dan pasal 20 ayat (1) yang menyatakan: "Komisi Pemberantasan Korupsi bertanggung jawab pada publik atas pelaksanaan tugasnya dan menyampaikan laporannya secara terbuka dan berkala kepada Presiden Republik Indonesia, Dewan Perwakilan Rakyat Republik Indonesia, dan Badan Pemeriksa Keuangan.

Komisi Pemberantasan Korupsi atau KPK adalah lembaga negara bantu yang dalam melaksanakan tugas dan wewenangnya bersifat independen dan bebas dari pengaruh kekuasaan manapun. Walaupun memiliki independensi dan kebebasan dalam melaksanakan tugas dan kewenangannya, namun Komisi Pemberantasan Korupsi tetap bergantung kepada cabang kekuasaan lain dalam hal yang berkaitan dengan perangkat keanggotaannya. Di samping itu, untuk menjamin perkuatan pelaksanaan tugas dan wewenangnya, Komisi Pemberantasan Korupsi dapat mengangkat tim penasehat yang berasal dari berbagai bidang kepakaran yang bertugas member nasehat atau pertimbangan kepada Komisi Pemberantasan Korupsi. Adapun mengenai aspek kelembagaan, ketentuan

\footnotetext{
${ }^{12}$ Ibid, Penjelasan pasal 3

13 Tjokorda Gde Indraputra, I Nyoman Bagiastra, Kedudukan Komisi Pemberantasan Korupsi Sebagai Lembaga Negara Bantu (State Auxiliary Institutions), Jurnal Kertha Negara 2(5), 2014.
} 
e-ISSN : 2621-4105

mengenai struktur organisasi Komisi Pemberantasan Korupsi diatur sedemikian rupa sehingga memungkinkan masyarakat luas luas tetap ikut berpartisipasi dalam aktivitas dan langkah-langkah dilakukan oleh Komisi Pemberantasan Korupsi, serta pelaksanaan program kampanye public dapat dilakukan secara sistematis dan konsisten, sehingga kinerja Komisi Pemberantasan Korupsi dapat diawasi oleh masyarakat luas.

Sebagai lembaga yang dibentuk untuk memberantas tindak pidana korupsi, Komisi Pemberantasan Korupsi bertugas mengoordinasikan serta melakukan penyelidikan, penyidikan, dan penuntutan terhadap tindak pidana korupsi. Lebih dari itu, Komisi Pemberantasa Korupsi juga diberikan kewenangan untuk mengambil alih penyidikan atau penuntutan terhadap pelaku tindak pidana korupsi yang sedang dilakukan oleh kepolisian atau kejaksaan. Salah satu alasan yang dapat dijadikan dasar oleh KPK untuk mengambil alih penyidikan atau penuntutan tersebut adalah adanya hambatan penanganan tindak pidana korupsi karena campur tangan dari pihak eksekutif, yudikatif, atau legislatif.

Walaupun memiliki independensi dan kebebasan dalam melaksanakan tugas dan kewenangannya, namun Komisi Pemberantasa Korupsi tetap bergantung kepada cabang kekuasaan lain dalam hal yang berkaitan dengan keorganisasian. Pasal 30 Undang-undang No 19 Tahun 2019 Tentang Perubahan Kedua Atas Undang-Undang Nomor 30 Tahun 2002 tentang Komisi Pemberantasa Korupsi menentukan bahwa pimpinan Komisi Pemberantasa Korupsi yang terdiri dari satu ketua dan empat wakil ketua, yang semuanya merangkap sebagai anggota, dipilih oleh DPR berdasarkan calon anggota yang diusulkan oleh Presiden.

Segala hal yang berkaitan dengan hubungan kedudukan antara Komisi Pemberantasan Korupsi dengan lembaga-lembaga negara lain selalu mengacu kepada Undang-undang No 19 Tahun 2019 Tentang Perubahan Kedua Atas Undang-Undang Nomor 30 Tahun 2002 tentang Komisi Pemberantasan Korupsi. Oleh karena itu, pengaturan mengenai hal tersebut tidak dibentuk secara khusus. Tugas dan kewenangan yang serupa dengan lembaga kejaksaan membuat Komisi Pemberantasan Korupsi terkesan lebih dekat dengan cabang kekuasaan eksekutif dibandingkan dengan cabang kekuasaan legislatif maupun yudikatif. Aturan-aturan tertulis yang digunakan Komisi Pemberantasan Korupsi. dalam 
e-ISSN : 2621-4105

melaksanakan tugas selain melakukan pemberantasan korupsi pun merupakan aturanaturan yang dibentuk oleh pemerintah (eksekutif).

Satu hal yang perlu ditegaskan terkait dengan kedudukan Komisi Pemberantasan Korupsi adalah bahwa rumusan dalam Pasal 3 Undang-undang No 19 Tahun 2019 Tentang Perubahan Kedua Atas Undang-Undang Nomor 30 Tahun 2002 Pemberantasan tentang Komisi Pemberantasan Korupsi tidak memberikan kemungkinan adanya penafsiran lain selain yang terumuskan dalam ketentuan Pasal tersebut, yaitu independensi dan kebebasan Komisi Pemberantasan Korupsi dari pengaruh kekuasaan manapun dalam melaksanakan tugas dan wewenangnya.

Komisi Pemberantasan Korupsi sendiri dibentuk dengan latar belakang bahwa upaya pemberantasan tindak pidana korupsi yang telah dilakukan hingga sekarang belum dapat dilaksanakan secara optimal. Lembaga yang menangani perkara tindak pidana korupsi belum berfungsi secara efektif dan efisien dalam memberantas tindak pidana korupsi, sehingga pembentukan lembaga seperti Komisi Pemberantasan Korupsi dapat dianggap penting secara konstitusional (constitutionally important) dan termasuk lembaga yang fungsinya masuk kedalam rumpun kekuasaan Eksekutif.

Sehubungan dengan keberadaan Komisi Pemberantasan Korupsi sebagai lembaga negara yang tidak ditempatkan dalam konstitusi, Romli berpendapat bahwa sistem ketatanegaraan tidak dapat diartikan hanya secara normatif (hanya dari sudut ketentuan konstitusi), tetapi juga dapat diartikan secara luas karena tidak semua lembaga negara diatur dalam konstitusi. Apabila suatu lembaga negara tidak ditempatkan di dalam Undang-undang Dasar Negara Republik Indonesia Tahun 1945, bukan berarti lembaga negara tersebut tidak mempunyai kedudukan hukum atau inkonstitusional, karena sifat konstitusional suatu lembaga dapat dilihat dari fungsinya dalam melaksanakan tugas dan wewenang atas nama negara. Dengan demikian, keberadaan lembaga negara ada yang tercantum di dalam Undang-undang Dasar Negara Republik Indonesia Tahun 1945 dan ada pula yang tidak tercantum dalam Undangundang Dasar Negara Republik Indonesia Tahun 1945melainkan dibentuk berdasarkan Undang-undang, termasuk Komisi Pemberantasan Korupsi sebagai sebuah lembaga negara bantu. $^{14}$

Tidak kalah pentingnya, latar belakang didirikannya Komisi Pemberantasan Korupsi telah ditegaskan dalam Penjelasan Umum Undang-undang No 19 Tahun 2019 Tentang

\footnotetext{
${ }^{14}$ Putusan MK RI Nomor 012-016-019/PUU-IV/2006, hal 133.
} 
e-ISSN : 2621-4105

Perubahan Kedua Atas Undang-Undang Nomor 30 Tahun 2002 tentang Komisi Pemberantasan Korupsi yang antara lain menyatakan bahwa tindak pidana korupsi di Indonesia sudah meluas dan berkembang secara sistematis di segala bidang kehidupan masyarakat, bangsa, dan negara sehingga telah melanggar hak- hak ekonomi dan hak-hak sosial masyarakat. Oleh karena itu, tindak pidana korupsi tidak dapat lagi digolongkan sebagai kejahatan biasa melainkan telah menjadi suatu kejahatan luar biasa (extraordinary crime), dan penanganannya pun tidak lagi dapat dilakukan secara konvensional melainkan harus dilaksanakan dengan cara-cara luar biasa. Salah satu langkah dalam rangka pelaksanaan cara luar biasa tersebut adalah pembentukan badan baru yang diberikan kewenangan yang luas, independen, serta bebas dari kekuasaan manapun (extra-ordinary tool). Dengan demikian, Keberadaan lembaga negara ada yang tercantum di dalam UUD Negara Republik Indonesia Tahun 1945 dan ada pula yang dibentuk berdasarkan undangundang, diantaranya Komisi Pemberantasan Korupsi yang disebut sebagai lembaga negara bantu. Dengan demikian, keberadaan lembaga Komisi Pemberantasan Korupsi secara yuridis adalah sah berdasarkan konstitusi dan secara sosiologis telah menjadi kebutuhan bangsa dan Negara Republik Indonesia.

Demikian Pembahasan dapat di ambil kesimpulan sementara kalau Komisi Pemberantasan Korupsi atau KPK adalah lembaga negara bantu yang masuk dalam rumpun kekuasaan eksekutif yang dalam melaksanakan tugas dan wewenangnya bersifat independen dan bebas dari pengaruh kekuasaan manapun.

\section{Kedudukan Komisi Pemberantasan Korupsi Yang Seharusnya Dalam Sistem Ketatanegaraan Di Indonesia}

Bahwa telah di bahas sebelumnya kalau Komisi Pemberantasan Korupsi adalah lembaga negara dalam rumpun kekuasaan eksekutif yang dalam melaksanakan tugas dan wewenangnya bersifat independen dan bebas dari pengaruh kekuasaan manapun serta lembaga Negara yang bersifat sebagai State auxiliary agency atau Lembaga Negara Bantu yang masuk dalam rumpun eksekutif.

State auxiliary agency atau State auxiliary agency atau lembaga Negara bantu biasanya berbentuk munculah organisasi-organisasi negara baru yang berupa dewan (council), komisi (commission), komite (committee), badan (board), atau otorita (authority). ${ }^{15}$ state

\footnotetext{
${ }^{15}$ Jimly Asshiddiqie (b), Op.Cit, hal V
} 
e-ISSN : 2621-4105

auxiliary organs atau state auxiliary institutions yang di terjemahkan dalam bahasa Indonesia adalah sebagai organisasi negara bantu dan merupakan organisasi negara yang berfungsi sebagai penunjang organisasi lain. Sebagian organisasi-organisasi tersebut di kenal juga sebagai self regulatory agencies, independent supervisory bodies, atau organisasi-organisasi yang menjalankan fungsi campuran (mix-function) antara fungsifungsi regulasi, admistranstrif, dan fungsi pengadilan yang biasanya dipisah-pisahkan akan tetapi malah dijalankan secara bersama oleh organisasi-organisasi baru tersebut. ${ }^{16}$

Fenomena munculnya sebuah lembaga bantu tersebut telah ikut mempengaruhi sistem ketatanegaraan dibanyak negara. Pada konteks ketatanegaraan Indonesia, ada kecendrungan dalam teori dan praktek administrasi untuk mengalihkan tugas-tugas yang bersifat regulatif dan administratif menjadi bagian dari tugas dari tugas cabang kekuasaan yang baru. Misalnya, kewenangan penindakan (penyelidikan, penyidikan, penuntutan, dan penyitaan dan pencegahan atas tindak pidana korupsi dilaksanakan pula oleh Komisi Pemberantasan Korupsi (KPK).

Independensi, kedudukan, dan ruang lingkup kewenangan lembaga-lembaga bantu tersebut juga bervariasi tidak ada tolak ukur kesamaan secara teori untuk membentuk Independensi, kedudukan, dan ruang lingkup kewenangan lembaga-lembaga tersebut. Begitu pula untuk wilayah berlakunya kebanyakan bersifat nasional, namun ada pula yang terbatas pada daerah tertentu saja. Keberadaan lembaga negara bertujuan untuk mencapai tujuan negara. Hal itu dapat diperjelas kembali dengan melihat beberapa pendapat ahli. Menurut Sri Soemantri ditetapkannya lembaga-lembaga negara dalam Undang-Undang Dasar bertujuan untuk mencapai tujuan negara.

Salah satu sifat organ negara penunjang (Auxiliary State`s Organ) seperti Komisi Pemberantasan Korupsi yakni Independen, yang sering disebut dengan istilah seperti komisi negara indepeden atau lembaga negara independen yang dsalah satunya adalah Komisi Pemberantasan Korupsi. Komisi negara independen adalah organ negara (state organs) yang diidealkan independen dan karenanya berada di luar kekuasaan eksekutif, legislatif maupun yudikatif. Pengertian dasar dari istilah independen adalah adanya kebebasan, kemerdekaan, kemandirian, otonom (otonomi), tidak dalam dominasi personal maupun institusional. Sehingga, ada pelaksanaan kehendak bebas (free will) yang dapat terwujud tanpa ada pengaruh yang secara signifikan merubah pendiriannya untuk membuat

\footnotetext{
${ }^{16}$ Ibid
} 
e-ISSN : 2621-4105

keputusan atau kebijakan. Oleh karena itu, komisi negara independen berbeda dengan komisi negara biasa.

Berdasarkan kedua pengaturan a quo terlihat jelas pergeseran format kelembagaan KPK yang independent terbebas dari pengaruh manapun menjadi KPK yang masuk dalam lingkup eksekutif. Rasanya kontradiktif bahkan terkesan menegasikan makna independen. Di satu sisi, KPK dalam menjalankan tugas dan wewenang yang dimilikinya kini tetap bersifat independen dan bebas dari pengaruh kekuasaan manapun, di sisi lain KPK secara kelembagaan masuk dalam rumpun eksekutif. Apakah mungkin KPK bisa bekerja secara efektif seperti dahulu jika KPK terkungkung dalam kekuasaan eksekutif. ${ }^{17}$

Keberadaan Komisi Pemberantasan Korupsi sering disamakan dengan keberadaan lembaga penunjang lainnya yang dibentuk oleh eksekutif. Keberadaan Komisi Pemberantasan Korupsi setidaknya harus dibedakan dengan lembaga negara eksekutif. Secara umum lembaga lembaga pemerintah dapat dibagi kedalam empat katagori. Pertama, ada departemen eksekutif yang disebut dalam Konstitusi, yang disatukan dengan para pejabat kabinet yang mengontrol mereka. Kedua, ada sub-kelembagaan yang ada didalam departemen-departemen ini, tetapi secara organisasi terpisah. Ketiga, ada juga lembaga- lembaga yang terpisah dari departemen eksekutif, tetapi sebenarnya "eksekutif". Keempat, lembaga- lembaga yang dibentuk secara "independen" oleh yudikatif dan juga dirujuk sebagai "lembaga- lembaga regulasi.

Keberadaan Komisi Pemberatasan Korupsi sebagai lembaga indepeden setidaknya harus dibedakan dengan lembaga negara eksekutif. Adapun, alasan mengapa Komisi Pemberantasan Korupsi sebagai lembaga independen dibentuk, dalam menjalankan fungsi dan tugasnya tidak mendapatkan tekanan dari kekuatan politik, karena hal ini dapat berdampak negatif ketika lembaga tersebut melaksanakan tugasnya. Jadi, kepastian sikap tidak berpihak dan tidak adanya kontrol politik adalah sangat penting dalam pelaksanaan tugas dan wewenangnya. Beberapa komisi negara indepeden bahkan secara umum menjadi organ konstitusi (constitusional organs), yang berarti eksistensinya dan fungsinya diatur dalam konstitusi. Sebagai contoh, Afrika Selatan merupakan salah satu negara yang secara

${ }^{17}$ Nehru Asyikin, Adam Setiawan, Kedudukan KPK Dalam Sistem Ketatanegaraan Pasca Diterbitkannya Revisi Undang-Undang KPK, Jurnal Justitia 4(1), 2020, hlm 138.

http://dx.doi.org/10.30651/justitia.v4i1.3736 
e-ISSN : 2621-4105

tegas mengatur keberadaan komisi-komisi negara yang bersifat independen dalam konstitusinya yang meliputi kewenangan, tugas, keanggotaan dan hubungan kerja dengan lembaga lain. Selain Afrika Selatan, negara Thailand, Filipina dan Korea Selatan juga secara tegas mengatur keberadaan komisi indepeden seperti dalam konstitusi. Oleh karena itu, terdapat aspirasi dari masyarakat menginginkan Komisi Pemberantasan Korupsi di Indonesia di atur dalam Konstitusi. Mengingat secara konstitusional Undang-undang Dasar Negara Republik Indonesia Tahun 1945 setelah perubahan belum mengatur hal tesebut, maka aspirasi tersebut menginginkan adanya perubahan kembali terhadap Undang-undang Dasar Negara Republik Indonesia Tahun 1945.

Ide pembaruan yang menyertai pembentukan lembaga-lembaga baru pada umumnya didasarkan atas dorongan untuk mewujudkan lembaga yang memiliki suatu idealisme serta mendorong suatu moderenisasi dan efektifitas pelayanan. Akan tetapi, yang menjadi masalah ialah proses pembentukan lembaga-lembaga baru itu tumbuh cepat tanpa didasari atas desain yang matang dan komperhesif. Masalah lain yang muncul ialah kedudukannya dalam struktur ketatanegaraan. ${ }^{18}$ Sebagian pandangan mengatakan bahwa organ yang berada di konstitusi sifatnya lebih permanen, dibanding yang berada diperaturan perundang-undangan dibawahnya. Hingga saat ini kita masih mendengar perdebatan soal permanen atau tidaknya komisi pemberantasan korupsi yang biasa disebut KPK, oleh karena tugasnya yang dianggap sementara, hingga kejaksaan dan kepolisian berfungsi dengan baik. Seperti di Negara Thailand yang awalanya lembaga anti korupsinya bernama juga Counter Corruption Commission (CCC), komisi antikorupsi yang dalam pelaksanaan tugasnya bertanggung jawab kepada perdana menteri. Dalam perjalanannya, komisi ini dianggap berjalan tidak efektif karena wewenangnya yang terbatas dan pertanggungjawabannya yang tidak independen. Untuk menjawab kondisi itu, pada 8 November 1999, dibentuklah undang-undang baru yang diberi nama Organic Act on Counter Corruption. Sejalan dengan undang-undang baru tersebut, berdiri pula komisi antikorupsi baru yang diharapkan dapat menunjukkan kinerja lebih baik daripada komisi serupa sebelumnya. Komisi Nasional Pemberantasan Korupsi atau The National Counter Corruption Commission (NCCC) memiliki satu orang ketua (presiden) dan delapan orang anggota yang semuanya diangkat oleh raja atas nasihat senat. karena diatur

\footnotetext{
${ }^{18}$ Gunawan A. Tauda, Komisi Negara Independen (Eksistensi Independent Agencies sebagai Cabang Kekuasaan baru dalam Sistem Ketatanegaraan), Genta Press, Yogyakarta, 2012, hal. 148
} 
e-ISSN : 2621-4105

secara sangat rapi dan terperinci. NCCC juga sangat independen dalam hal pertanggungjawaban, yaitu kepada rakyat melalui parlemen ${ }^{19}$ dan masuk ke dalam Konstitusi Thailand. Lembaga Anti Korupisi seperti Komisi Pemberantasan Korupsi di dunia Internasional ada kecenderungan harus secara eksplisit dimuat di dalam konstitusi. ${ }^{20}$ Zainal Arifin Mochtar berpendapat bahwa Komisi Pemberantasan Korupsi memang sebaiknya diatur dalam konstitusi, Kedududukan Komisi Pemberantasan Korupsi dalam sistem ketatanegaran di Indonesia akan menjadi lebih kuat ketika dicantumkan di konstitusi. $^{21}$

Demi menjawab tantang dimasa yang akan datang maka dibutuhkan suatu konsep baru dalam menjalankan fungsi dari suatu bangsa untuk menjamin kesejahteraan dan kemakmuran dari rakyat demi terwujudnya cita-cita dari negara Indonesia serta Komisi Sebagai penegakan hokum di Indonesia dengan menginisiasinya sesuai kebutuhan masyarakat. ${ }^{22}$ Berdasar uraian diatas Komisi Pemberantasan Korupsi perlu di jadikan organ konstitusi (constitusional organs), yang berarti eksistensinya dan fungsinya diatur dalam konstitusi.

Seharusnya Indonesia mencontoh negara Thailand yang memasukan Lembaga anti korupsinya kedalam konstitusi atau undang undang dasar supaya Komisi Pemberantasan Korupsi di Indonesia lebih Independen dan kedudukannya dalam sistem ketatanegaraan di Indonesia lebih kuat lagi. Untuk mewujudkan semua itu Komisi Pemberantasan Korupsi yang Independen bebas dari pengaruh kekuasaan manapun dan kedudukannya dalam sistem ketatanegaraan di Indonesia menjadi organ konstitusi (constitusional organs) maka di perlukan Amandemen Undang-undang Dasar Negara Republik Indonesia Tahun 1945.

Tanpa adanya Amandemen Undang-undang Dasar Negara Republik Indonesia Tahun 1945 dan memasukan Komisi Pemberantasan Korupsi organ konstitusi (constitusional organs) maka Komisi Pembearantasa Korupsi tetap menjadi State auxiliary agency atau

\footnotetext{
${ }^{19}$ Hamzah, Loc. cit., hal. 67-76

${ }^{20} \mathrm{https}$ ://www.voaindonesia.com/a/pusat-kajian-anti-korupsi-kpk-perlu-masukkonstitusi/1563431.html, di Akse pada 6 Agustus 2020

${ }^{21}$ Ibid.

${ }^{22}$ Muhammad Junaidi, Semangat Pembaharuan Dan Penegakan Hukum Indonesia Dalam Perspektif Sociological Jurisprudence, Jurnal Pembaruan Hukum 3(1), 2016, hlm 48-63. http://dx.doi.org/10.26532/jph.v3i1.1346
} 
e-ISSN : 2621-4105

lembaga negara bantu dan keberandanya yang dianggap sementara, hingga kejaksaan dan kepolisian berfungsi dengan baik .

Demikian hasil penelitian ini, dapat di ambil kesimpulan dari pembahasan ini adalah untuk mewujudkan Komisi Pemberantasan Korupsi bebas dari pengaruh kekuasaan manapun dan kedududukan Komisi Pemberantasan Korupsi dalam sistem ketatanegaran di Indonesia akan menjadi lebih kuat maka kedudukannya menjadi organ konstitusi (constitusional organs) atau dimasukan ke dalam konstitusi maka di perlukan Amandemen Undangundang Dasar Negara Republik Indonesia Tahun 1945.

\section{E. PENUTUP}

Kedudukan Komisi Pemberantasan Korupsi atau KPK dalam sistem ketatanegaraan di Indonesia adalah sebagai lembaga negara bantu yang masuk dalam rumpun kekuasaan eksekutif yang dalam melaksanakan tugas dan wewenangnya bersifat independen dan bebas dari pengaruh kekuasaan manapun. Untuk mewujudkan Komisi Pemberantasan Korupsi bebas dari pengaruh kekuasaan manapun dan Kedududukan Komisi Pemberantasan Korupsi dalam sistem ketatanegaran di Indonesia akan menjadi lebih kuat maka kedudukannya harus menjadi organ konstitusi (constitusional organs) atau dimasukan ke dalam konstitusi maka di perlukan Amandemen Undang-undang Dasar Negara Republik Indonesia Tahun 1945.

\section{DAFTAR PUSTAKA}

\section{Buku}

Firmansyah Arifin dkk., Organisasi Negara dan Sengketa Kewenangan Antarorganisasi Negara, Konsorsium Reformasi Hukum Nasional (KRHN), Jakarta, 2005.

Gunawan A. Tauda, Komisi Negara Independen (Eksistensi Independent Agencies sebagai Cabang Kekuasaan baru dalam Sistem Ketatanegaraan), Genta Press, Yogyakarta, 2012.

Jimly Asshiddiqie (b), Perkembangan dan Konsolidasi Organisasi Negara Pasca Reformasi, Sekretaris Jenderal dan Kepaniteraan Mahkamah Konstitusi RI, Jakarta, 2006.

Mahmuddin Muslim, Jalan Panjang Menuju KPTPK, Gerakan Rakyat Anti Korupsi (GeRAK) Indonesia, Jakarta, 2004.

Soerjono Soekanto dan Sri Mamudji, Penelitian Hukum Normatif Suatu Tinjauan Singkat, PT. Raja Grafindo Persada, Jakarta 2007.

\section{Jurnal}


e-ISSN : 2621-4105

Adri Fernando Roleh, Kedudukan Komisi Pemberantasan Korupsi Dalam Sistem Ketatanegaraan Indonesia, Lex Privatum 5 (10), 2017.

Aryas Adi Suyanto, “Komisi Pemberantasan Korupsi Sebagai Lembaga Rasuah dalam Pemberantasan Tindak Pidana Korupsi di Indonesia", Jurnal USM Law Review 1 (1), 2018. DOI: 10.26623/julr.v1i1.2231.

Ismail Aris, Kedudukan KPK Dalam Sistem Ketatanegaraan Dalam Perspektif Teori The New Separation Of Power, Jurnal Jurisprudentie 5 (1), 2018.

https://doi.org/10.24252/jurisprudentie.v5i2.5433

Mellysa Febriani Wardojo,Didik Endro Purwoleksono, Kedudukan Komisi Pemberantasan Korupsi Sebagai Lembaga Negara, Jurnal Legal Standing 2 (1), 2018. https://doi.org/10.24252/jurisprudentie.v5i2.5433

Muhammad Junaidi, Semangat Pembaharuan Dan Penegakan Hukum Indonesia Dalam Perspektif Sociological Jurisprudence, Jurnal Pembaruan Hukum 3 (1) 2016. http://dx.doi.org/10.26532/jph.v3i1.1346

Nehru Asyikin, Adam Setiawan, Kedudukan KPK Dalam Sistem Ketatanegaraan Pasca Diterbitkannya Revisi Undang-Undang KPK, Jurnal Justitia 4 (1), 2020. http://dx.doi.org/10.30651/justitia.v4i1.3736

Tjokorda Gde Indraputra, I Nyoman Bagiastra, Kedudukan Komisi Pemberantasan Korupsi Sebagai Lembaga Negara Bantu (State Auxiliary Institutions), Jurnal Kertha Negara 2 (5), 2014.

Yopa Puspitasari, Kedudukan Komisi Pemberantasan Korupsi Dalam Struktur Ketatanegaraan Indonesia Ditinjau Dari Hukum Islam, Jurnal Al-Imarah: Jurnal Pemerintahan dan Politik Islam 4 (2), 2019.

http://dx.doi.org/10.29300/imr.v4i2.2830

\section{Peraturan Perundang-undangan}

Undang-undang No 19 Tahun 2019

Putusan MK RI Nomor 012-016-019/PUU-IV/2006

\section{Internet}

https://www.voaindonesia.com/a/pusat-kajian-anti-korupsi-kpk-perlu-masukkonstitusi/1563431.html, 